\title{
Consórcio na entrelinha de sorgo com braquiária na safrinha para produção de grãos e forragem
}

\section{Interrow intercropping of sorghum with brachiaria in off-season cultivation to production grains and forage}

\author{
Alessandro Guerra da Silva ${ }^{1,5^{*}}$; Luiz Eduardo de Moraes $^{2}$; \\ Adalbert Horvathy Neto ${ }^{3,6}$; Itamar Rosa Teixeira ${ }^{4,5}$; Gustavo André Simon ${ }^{1}$
}

\begin{abstract}
Resumo
O consórcio tem-se mostrado como técnica de cultivo eficaz para maximização da produção a partir do cultivo simultâneo de diferentes espécies na mesma área. Assim, objetivou-se com este trabalho avaliar, na safrinha, a produção de grãos e forragem na entressafra por meio do consórcio na entrelinha de sorgo granífero com braquiária em duas profundidades de semeadura. $\mathrm{O}$ experimento foi implantado a campo em Rio Verde-GO, no dia 05 de março de 2009. O delineamento experimental utilizado foi o de blocos casualizados, em esquema fatorial $2 \times 3+1+3$, com quatro repetições, correspondendo a duas profundidades de semeadura da braquiária $(2$ e $10 \mathrm{~cm}$ ), três espécies de braquiária (Brachiaria decumbens, $B$. brizantha $\mathrm{cv}$. Marandú e $B$. ruziziensis) e quatro tratamentos adicionais referentes aos monocultivos de sorgo e três espécies de braquiárias. O sorgo granífero utilizado foi o DKB 599. A avaliação do rendimento de forragem das braquiárias foi realizada aos 98 dias após a colheita do sorgo. Os resultados permitiram constatar que os consórcios na entrelinha de sorgo com B. ruziziensis, independente da profundidade de semeadura, e $\operatorname{com} B$. brizantha, semeada a $2 \mathrm{~cm}$ de profundidade, não causaram reduções no rendimento de grãos. $\mathrm{O}$ cultivo de braquiária na entrelinha do sorgo possibilitou incrementos nos rendimentos de massa seca e proteína bruta total da forragem. O consórcio de sorgo com braquiária na safrinha mostrou-se como técnica de cultivo promissora para produção de grãos e forragem (massa seca e proteína bruta) na entressafra em condições de cerrado.

Palavras-chave: Sorghum bicolor, Brachiaria, profundidade de semeadura, entressafra, associação de culturas, rendimento de grãos
\end{abstract}

\footnotetext{
Abstract

The intercropping has been shown as effective cultivation technique to rise the production from the simultaneous cultivation of different species in the same area. Thus, the objective of this research was to evaluate, in off-season cultivation, the forage and grains production in off-season by interrow intercropping of grain sorghum with brachiaria in two sowing depths. The experiment was carried out in field in Rio Verde-GO, on March 5, 2009. The experimental design used was the randomized blocks in factorial scheme $2 \times 3+1+3$ with four replications, corresponding to two brachiaria sowing

${ }^{1}$ Profs. do Programa de Pós-Graduação em Produção Vegetal, PPGPV, Faculdade de Agronomia, Universidade de Rio Verde, UniRV, Rio Verde, GO. E-mail: silvaag@yahoo.com.br; guasimon@yahoo.com.br

2 Eng $^{\circ}$ Agr $^{\circ}$, UniRV, Rio Verde, GO. E-mail: dumoraes86@hotmail.com

${ }^{3}$ Discente do Curso de Mestrado do Programa de Pós-Graduação em Produção Vegetal, PPGPV, UniRV, Rio Verde, GO. E-mail: adalberthorvathy@gmail.com

${ }^{4}$ Prof. do Programa de Pós-Graduação em Engenharia Agrícola da Universidade Estadual de Goiás, Unidade de Anápolis, UnUCET, Anapólis, GO. E-mail: itamar.teixeira@pq.cnpq.br

5 Bolsistas de Produtividade em Pesquisa do Conselho Nacional de Desenvolvimento Científico e Tecnológico, CNPq.

${ }^{6}$ Bolsista da Coordenação de Aperfeiçoamento de Pessoal de Nível Superior, CAPES.
}

* Autor para correspondência 
depths $(2$ and $10 \mathrm{~cm}$ ), three brachiaria species (Brachiaria decumbens, B. brizantha $\mathrm{cv}$. Marandú and B. ruziziensis) and four additional treatments of sorghum and three brachiaria species (monocultures). The grain sorghum used was the DKB 599. The evaluation of the brachiaria forage yield was made up at 98 days after the sorghum harvest. The interrow intercropping of sorghum with Brachiaria ruziziensis, regardless the sowing depth, and with $B$. brizantha, sowed in $2 \mathrm{~cm}$ depth, did not cause reductions in grain yield. The interrow intercropping with brachiaria possible increases in dry matter and crude protein total yields of the forage. The sorghum and brachiaria intercropping in off-season cultivation shows to be a promising cultivation technique to produce grains and forage (dry matter and crude protein) in cerrado conditions.

Key words: Sorghum bicolor, Brachiaria, sowing depth, off-season, crop association, grain yield

\section{Introdução}

Atualmente a demanda pelo milho para uso na alimentação animal tem aumentado significativamente. Porém a produção às vezes não tem acompanhado a evolução do consumo, levando a procura de culturas alternativas para uso como matéria prima nas agroindústrias instaladas na região Centro-Oeste.

Entre as culturas produtoras de grãos, destacase o sorgo (HECKLER, 2002; SILVA et al., 2009a), pelo valor nutritivo semelhante ao do milho, menor custo de produção (COELHO et al., 2002) e pela boa adaptação a diferentes ambientes (PALE; MASON; GALUSHA, 2003; BAUMHARDT; TOLK; WINTER, 2005; DAN et al., 2010), principalmente onde ocorre déficits hídricos (MARIGUELE; SILVA, 2002; CYSNE; PITOMBEIRA, 2012), como ocorre na safrinha na região centro-oeste.

Nesta região, os produtores rurais tem dificuldade em produzir forragem e/ou palhada no período da entressafra para a manutenção do sistema plantio direto (KLIEMANN; BRAZ; SILVEIRA, 2006; BORGHI; CRUSCIOL, 2007). Sendo assim, as culturas de safrinha são fundamentais para a implantação e viabilização do plantio direto, principalmente quando apresentam maior relação $\mathrm{C} / \mathrm{N}$, proporcionando menor taxa de decomposição e mantendo assim a biomassa por maior tempo na superfície do solo (TORRES; PEREIRA; FABIAN, 2008). Isso possibilita a dissipação da energia do impacto das gotas de chuva, reduzindo a evaporação da água do solo, aumentando a eficiência da ciclagem dos nutrientes e ainda, auxiliando no controle de plantas daninhas (KLUTHCOUSKI et al., 2004).
Uma alternativa para produção de grãos e maior quantidade de forragem na entressafra seria a adoção do sistema de consorciação de culturas. O consórcio de sorgo com braquiária parece ser bastante promissor pois o sistema permite a produção de grãos e forragem (MATEUS et al., 2011) na entressafra, podendo a forragem da braquiária ser usada na forma de pastejo (MELLO et al., 2004). Adicionalmente, tem-se a vantagem de que as espécies da forrageira apresentarem sistema radicular abundante, contribuindo para a infiltração de água, para agregação e aeração do solo (KLUTHCOUSKI et al., 2004; SILVA et al., 2007), além do controle de plantas daninhas (BRAZ et al., 2006; CORREIA; DURIGAN; KLINK, 2007).

Devido à escassez de trabalhos científicos publicados abordando o consórcio de sorgo granífero com espécies forrageiras nos cerrados, é fundamental que se identifique a melhor associação de sorgo com espécies de braquiária, disponíveis para comercialização na região $(B$. brizantha, $B$. decumbens e $B$. ruziziensis), visando obtenção de maiores rendimentos de grãos e forragem em consórcio. Em função das diferenças morfológicas das espécies de braquiária (ASSIS et al., 2003), há a necessidade de se avaliar a implantação das mesmas em consórcio e a semeadura na mesma profundidade de aplicação do fertilizante (ALVARENGA et al., 2006), ou seja, abaixo da semente do sorgo, pode ser uma estratégia para retardar a emergência das plântulas de braquiária e diminuir, desta forma, a competição com as plantas de sorgo. 
Assim, o objetivo deste trabalho é o de avaliar, na safrinha, o consórcio na entrelinha de sorgo granífero com diferentes espécies de braquiária, em duas profundidades de semeadura, para produção de grãos e forragem na entressafra.

\section{Material e Métodos}

O experimento foi conduzido em campo em Rio Verde-GO (17²4’24,5' S; 5057’41,7' W; e $769 \mathrm{~m}$ de altitude) na safrinha de 2009. O solo da área experimental foi classificado como Latossolo Vermelho distrófico, cultivado no sistema de semeadura direta há cinco anos. A cultura que antecedeu à implantação do experimento foi a da soja.

Os resultados da análise química da amostra de solo da área experimental foram: $\mathrm{pH} \mathrm{em} \mathrm{CaCl}_{2}: 4,8$; $\mathrm{Ca}, \mathrm{K}, \mathrm{Mg}, \mathrm{Al}, \mathrm{H}+\mathrm{Al}$, CTC e SB: 1,03; 0,32; 0,66; 0,$05 ; 4,3 ; 6,3$ e 2,01, respectivamente, em cmol $\mathrm{dm}^{-}$

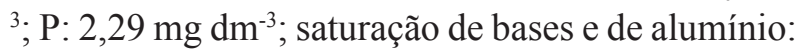
31,94 e $2,43 \%$; argila 590, silte 130 e areia $280 \mathrm{~g}$ $\mathrm{kg}^{-1}$. As médias de temperatura do ar e precipitação, por decêndio, durante a condução do ensaio estão dispostas na Figura 1, como também os períodos de colheita do sorgo e da braquiária.

Figura 1. Variação mensal da temperatura média do ar e precipitação de janeiro a dezembro de 2009, Rio Verde-GO (Fonte: Estação Climatológica da Universidade de Rio Verde - GO).

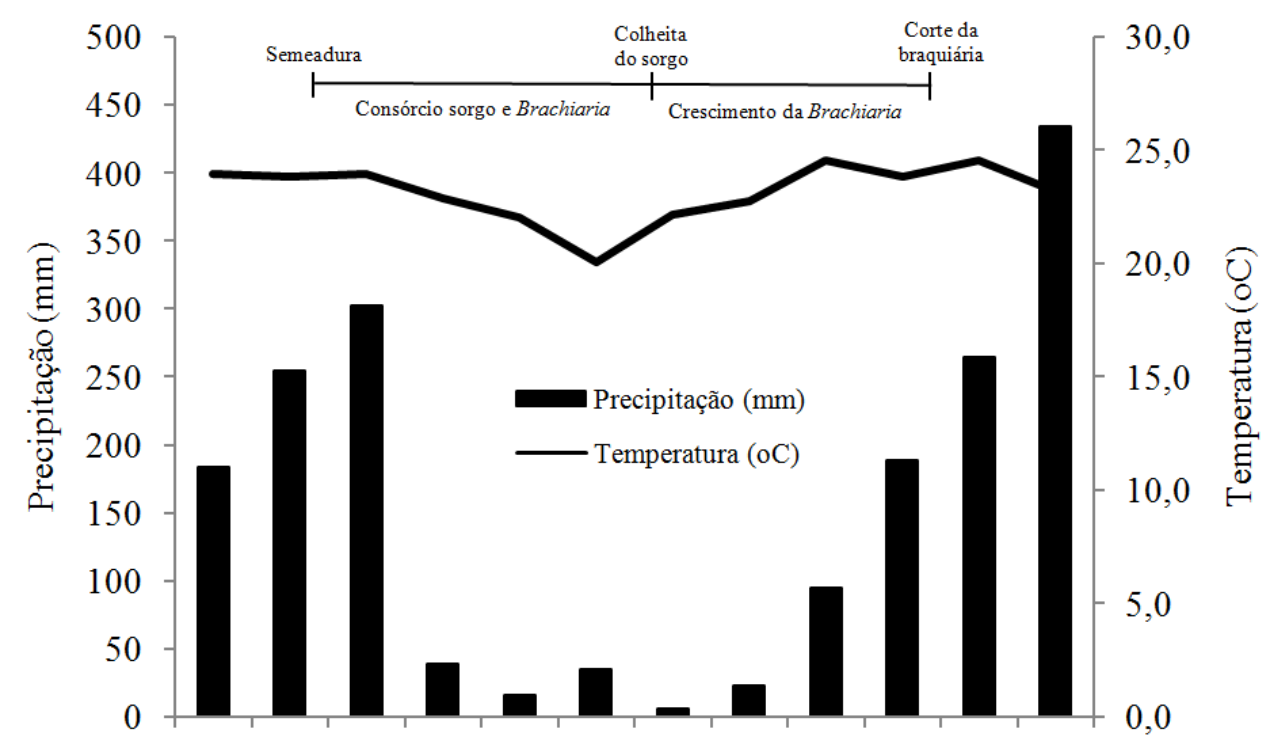

Jan Fev Mar Abr Mai Jun Jul Ago Set Out Nov Dez

Fonte: Elaboração dos autores.

O delineamento experimental empregado foi o de blocos casualizados, em esquema fatorial $2 \times 3+1+3$, com quatro repetições, correspondendo a duas profundidades de semeadura na entrelinha da braquiária (2 e $10 \mathrm{~cm}$; profundidades correspondentes à semeadura e aplicação do fertilizante, respectivamente, na cultura do sorgo), três espécies de braquiária (Brachiaria decumbens, $B$. brizantha cv. Marandú e B. ruziziensis) e quatro tratamentos adicionais referentes aos cultivos solteiros (monocultivos) do sorgo e das três espécies de braquiárias. Estes quatro tratamentos foram implantados na mesma sequência do ensaio de consórcio com o intuito de avaliar a eficiência 
do consórcio em relação aos monocultivos. As espécies de braquiária foram escolhidas em função da disponibilidade para comercialização e a grande demanda para uso na região Centro-Oeste.

O cultivar de sorgo utilizado foi o DKB 599 (caracterizado por ser precoce, de grãos vermelhos e sem tanino, sendo recomendado para sistemas de alta tecnologia). As parcelas foram constituídas de sete linhas de semeadura do sorgo, com 5,0 m de comprimento e espaçadas $0,45 \mathrm{~m}$ entre si. A área útil $\left(5,4 \mathrm{~m}^{2}\right)$ foi obtida, desconsiderando as duas fileiras laterais e $0,5 \mathrm{~m}$ de cada extremidade.

Aos sete dias antes da implantação do ensaio, foi realizado o manejo pré-semeadura das plantas daninhas de forma mecanizada, empregando o equivalente a $1.440 \mathrm{~g}$ e.a. $\mathrm{ha}^{-1}$ de glyphosate e 433,5 $\mathrm{g} \mathrm{ha}^{-1}$ de 2,4-D, utilizando volume de calda de $150 \mathrm{~L} \mathrm{ha}^{-1}$. Um dia antes da semeadura foi feito o sulcamento e adubação de semeadura na área, de forma mecânica. Nas entrelinhas, para semeadura da braquiária, os sulcos foram feitos de forma manual em profundidades correspondentes a implantação da forrageira. A semeadura de ambas as culturas foi realizada no dia 05 de março, sendo o sorgo semeado a $2 \mathrm{~cm}$ de profundidade e as braquiárias na entrelinha segundo os respectivos tratamentos. Para permitir a emergência das plântulas em menor tempo nos monocultivos, foi realizada a semeadura do sorgo e da braquiária a $2 \mathrm{~cm}$ de profundidade, semelhante ao que é feito nas propriedades agrícolas do Centro-Oeste (SILVA et al., 2009a). Para a implantação da braquiária levou-se em consideração o valor cultural (VC) das sementes (B. brizantha e B. ruziziensis: $75,6 \% ; 3,2 \mathrm{~kg} \mathrm{ha}^{-1} ; B$. decumbens: $34,1 \% ; 7,0 \mathrm{~kg} \mathrm{ha}^{-1}$ ), empregando a expressão (240 $\left.\mathrm{VC}^{-1}\right)$ para definição da quantidade de sementes, em $\mathrm{kg} \mathrm{ha}^{-1}$.

A adubação empregada na semeadura, no consórcio e no monocultivo, foi de $300 \mathrm{~kg} \mathrm{ha}^{-1}$ do fertilizante 02-20-18, sendo realizada cobertura, de forma manual, aos 25 dias após a emergência (DAE) ao lado da linha de semeadura do sorgo, empregando $100 \mathrm{~kg} \mathrm{ha}^{-1}$ de $\mathrm{N}$ na forma de uréia. Nesta mesma ocasião, foi realizado o desbaste do sorgo objetivando-se uma população equivalente a 180 mil plantas ha-1.

O controle das plantas daninhas em pósemergência foi realizado por meio de duas capinas manuais realizadas aos 20 e 35 DAE. Na fase de emborrachamento do sorgo (42 DAE) realizouse a aplicação de $50 \mathrm{~g} \mathrm{ha}^{-1}$ de cipermetrina com volume de calda de $150 \mathrm{~L} \mathrm{ha}^{-1}$ visando o controle de Spodoptera frugiperda.

A colheita do sorgo foi realizada aos 125 DAE, sendo avaliadas, na área útil das parcelas, as seguintes características: rendimento de grãos (colheita das panículas, com posterior debulha e pesagem dos grãos, com correção da umidade para 13\%); peso de 1.000 grãos (determinação do peso de mil grãos, escolhidos aleatoriamente na amostra de rendimento de grãos, com correção da umidade para 13\%); altura de plantas (medição do colo até a extremidade da panícula em cinco plantas escolhidas aleatoriamente); índice de perfilhamento (contagem do número de perfilhos em cinco plantas escolhidas aleatoriamente); estande final (contagem do número total de plantas colhidas); e acamamento de plantas (porcentagem do número de plantas acamadas).

As espécies de braquiária permaneceram no campo até 98 dias após a colheita do sorgo, momento em que realizaram-se as seguintes avaliações na área útil das parcelas: altura das plantas (medição do comprimento, por meio de uma régua graduada, do colo até a extremidade da última folha completamente expandida em cinco plantas escolhidas aleatoriamente; em função do acamamento, as plantas de braquiária foram completamente estendidas para facilitar a medição) e índice de perfilhamento (contagem do número médio de perfilhos de cinco plantas escolhidas aleatoriamente nas linhas úteis das parcelas, devido ao entrelaçamento das mesmas).

Também nesta mesma época, foram avaliados, para cada cultura, o rendimento de massa seca 
total da forragem (coleta, em $1 \mathrm{~m}^{2}$, da massa vegetal do sorgo e braquiária por meio do uso de um quadrado de ferro de dimensões de 1,0 $\mathrm{x}$ 1,0 m; as amostras foram acondicionadas em sacos de papel, separadamente, e levadas para secagem em estufa a $65^{\circ} \mathrm{C}$, determinando o peso seco e, em seguida, o rendimento de massa seca total, expressando os resultados em $\mathrm{kg} \mathrm{ha}^{-1}$ ) e o rendimento de proteína bruta total da forragem (as amostras de massa seca foram moídas em moinho do tipo Willey, com peneira de $1 \mathrm{~mm}$ de diâmetro, determinando, posteriormente, o teor de $\mathrm{N}$ pelo método microKjeldahl; os resultados obtidos foram multiplicados por 6,25 para se obter o teor de proteína bruta (MALAVOLTA; VITTI; OLIVEIRA, 1997) de cada espécie; em seguida efetuou-se o produto do rendimento de massa seca pelo teor de proteína bruta de cada espécie e os resultados foram somados para ser obter o rendimento de proteína bruta total, expressos em $\mathrm{kg} \mathrm{ha}^{-1}$ ).

Para cada espécie, quantificou-se também a relação $\mathrm{C} / \mathrm{N}$ da massa vegetal aos 98 dias após a colheita do sorgo. Nessa avaliação o C orgânico foi determinado pela queima das amostras em mufla à $550^{\circ} \mathrm{C}$ (EMBRAPA, 1997) e o $\mathrm{N}$ pelo método microKjeldahl, como relatado anteriormente, obtendo em seguida a relação $\mathrm{C} / \mathrm{N}$ para cada espécie. Um dia após a colheita do sorgo, quantificou-se a porcentagem de cobertura vegetal sobre o solo (avaliação em dois locais na área útil da parcela, com utilização de um quadrado de ferro de dimensões de 0,5 x 0,5 m, contendo uma linha com dez pontos separados equidistantes; a determinação da porcentagem de cobertura na superfície do solo foi computada quando esses pontos coincidiam com a presença de cobertura vegetal). E por fim, para avaliar a eficiência do consórcio, calculou- se o índice de equivalência de área (somatório da relação do rendimento de grãos de sorgo (consórcio/ monocultivo) e de massa seca (sorgo+braquiária/ monocultivo de braquiária)).

Após coletas todas as informações, realizouse a análise estatística utilizando os programas estatísticos SISVAR e Genes. Em uma primeira etapa, realizou-se a análise de variância individual e em seguida à análise combinada entre o consórcio e o monocultivo. Para a comparação das médias obtidas no consórcio e no monocultivo, empregouse, quando constatada significância, o teste de Tukey a 5\% de probabilidade. Efetuou-se também contrastes entre as médias obtidas no consórcio com as dos respectivos monocultivos (testemunhas). Nesse caso procedeu-se a análise pelo uso do teste de Dunnett a 5\% de probabilidade (PIMENTEL GOMES; GARCIA, 2002). Na análise do índice de equivalência de área, em que o valor obtido envolve informações oriundas do consórcio e monocultivo, empregou-se o esquema fatorial simples $2 \times 3$, referente às duas profundidades de semeadura e as três espécies de braquiária.

\section{Resultados e Discussão}

\section{Cultura do sorgo}

Os resultados da análise de variância para o rendimento de grãos de sorgo permitiram constatar significâncias $(p<0,01)$ para as fontes de variação Braquiária, interação Profundidade de semeadura x Braquiária e contraste Consórcio x Monocultivo (Tabela 1). Para as demais variáveis, somente foi constatada significância $(\mathrm{p}<0,05)$ para Consórcio $\mathrm{x}$ Monocultivo para a variável índice de perfilhamento do sorgo. 


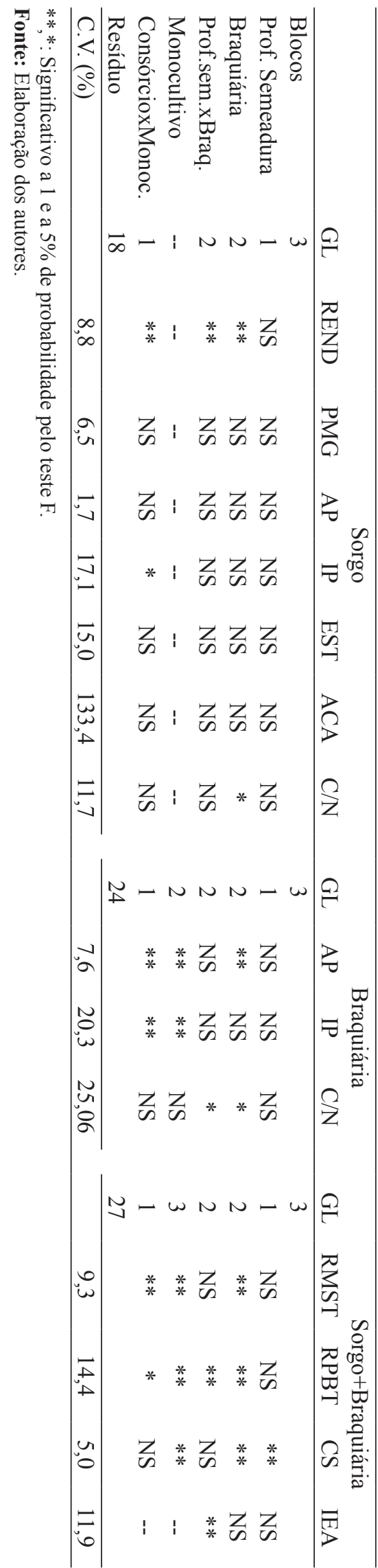

O rendimento de grãos foi superior quando o ํㅠㄹ. $2 \mathrm{~cm}$, sendo o mesmo verificado para a $B$. decumbens implantada a $10 \mathrm{~cm}$ (Tabela 2). Já a profundidade de semeadura da $B$ ruziziensis não influenciou o rendimento de grãos de sorgo. Quando as braquiárias foram semeadas a $2 \mathrm{~cm}$, e também de maneira geral, constatou-se que a associação do sorgo com a $B$. decumbens ocasionou a maior redução no rendimento de grãos de sorgo, sendo inferior ao valor obtido com as demais espécies (Tabela 2). Com a semeadura a $10 \mathrm{~cm}$ a maior interferência das plantas de braquiária no rendimento de grãos de sorgo ocorreu com a $B$. brizantha, ao contrário da associação com a $B$. ruziziensis que proporcionou maior rendimento.

Quando se compara o rendimento de grãos do sorgo em consórcio com os do monocultivo, podese constatar ausência de significância na associação com $B$. ruziziensis, independente da profundidade de semeadura, e com a $B$. brizantha semeada a $2 \mathrm{~cm}$ de profundidade (Tabela 2). Nestas combinações, o consórcio de braquiária na entrelinha do sorgo minimizou a competição das plantas das duas espécies por água, luz, nutrientes e espaço físico, permitindo que sorgo apresentasse rendimento semelhante ao obtido em monocultivo.

Ressalta-se que no consórcio não foi realizado nenhuma aplicação de herbicida para suprimir o crescimento das plantas de braquiária. Estes resultados demonstram a viabilidade do consórcio na entrelinha de sorgo granífero DKB 599 com braquiária para produção de grãos na safrinha. Para as demais associações, houve reduções expressivas no rendimento de grãos, como no consórcio com a $B$. decumbens. Talvez a maior competição entre as espécies deve-se ao melhor desempenho da $B$. decumbens em solos de baixa fertilidade (VILELA et al., 1998). Isso promoveu maior crescimento e consequentemente maior competição com as plantas de sorgo, reduzindo assim o rendimento de grãos. É oportuno destacar que em ambos sistemas de cultivo, apesar dos resultados de pesquisa 
serem escassos no que se refere ao rendimento do sorgo na safrinha, os valores obtidos apresentaram semelhanças aos de outros trabalhos de pesquisa realizados na região Centro-Oeste (HECKLER, 2002; SILVA et al., 2009a).

O índice de perfilhamento das plantas de sorgo permite avaliar se as plantas de braquiária ocasionaram competição. Mesmo com a redução no rendimento de grãos quando o consórcio foi realizado com a $B$. decumbens não foram constadas reduções expressivas no perfilhamento das plantas de sorgo em todas combinações. O fato da braquiária ser semeada nas entrelinhas da cultura do sorgo permitiu, nas primeiras semanas de desenvolvimento do sorgo, a incidência de luz nas gemas do terço inferior das plantas (LARCHER, 2003; TAIZ; ZEIGER, 2010), não proporcionando assim diferenças no perfilhamento entre os sistemas de cultivo.

A menor ou mesmo a ausência de interferência da braquiária, quando consorciada na entrelinha, na cultura do sorgo pode ser comprovada pela ausência de significância entre as fontes de variação para as variáveis peso de mil grãos, altura de plantas, estande e acamamento (Tabela 2). Portanto o consórcio na entrelinha com as plantas de braquiária é uma estratégia cultural para minimizar a competição destas com as plantas de sorgo, visto que nesta associação de culturas, não há registro de nenhum herbicida seletivo para o sorgo que suprime o crescimento das plantas de braquiária.

Tabela 2. Valores médios de rendimento de grãos (REND), índice de perfilhamento (IP), relação $\mathrm{C} / \mathrm{N}(\mathrm{C} / \mathrm{N})$, peso de mil grãos (PMG), altura (AP), estande (EST) e acamamento (ACA) da cultura do sorgo consorciado com B. brizantha $(B b), B$. decumbens $(B d)$ e $B$. ruziziensis $(B r)$ semeadas a 2 e $10 \mathrm{~cm}$ de profundidade na safrinha, Rio Verde-GO, $2009^{\prime 1}$.

\begin{tabular}{|c|c|c|c|c|}
\hline Consórcio & $B b$ & $B d$ & $B r$ & Média \\
\hline \multicolumn{5}{|c|}{ REND $\left(\mathrm{kg} \mathrm{ha}^{-1}\right)$} \\
\hline $2 \mathrm{~cm}$ & $2.696 \mathrm{Aa}$ & $1.429 \mathrm{Bb}^{*}$ & $2.896 \mathrm{Aa}$ & 2.340 \\
\hline $10 \mathrm{~cm}$ & $1.811 \mathrm{Bc}^{*}$ & $1.917 \mathrm{Ab}^{*}$ & $3.115 \mathrm{Aa}$ & 2.281 \\
\hline Média & $2.254 \mathrm{~b}$ & $1.673 \mathrm{c}$ & $3.005 \mathrm{a}$ & \\
\hline Monocultivo & 2.917 & & & \\
\hline \multicolumn{5}{|c|}{ IP (\%) } \\
\hline $2 \mathrm{~cm}$ & 4,29 & $5,14 *$ & 4,52 & 4,65 \\
\hline $10 \mathrm{~cm}$ & 4,31 & 4,83 & 3,63 & 4,26 \\
\hline Média & 4,30 & 4,99 & 4,08 & \\
\hline Monocultivo & 3,54 & & & \\
\hline \multicolumn{5}{|c|}{$\mathrm{C} / \mathrm{N}$} \\
\hline $2 \mathrm{~cm}$ & 101 & 94 & 99 & 98 \\
\hline $10 \mathrm{~cm}$ & 101 & 84 & 108 & 98 \\
\hline Média & $101 \mathrm{a}$ & $89 \mathrm{~b}$ & $103 \mathrm{a}$ & \\
\hline Monocultivo & 100 & \multicolumn{2}{|c|}{ Monocultivo } & \\
\hline & PMG (g) & $\mathrm{AP}(\mathrm{m})$ & $\operatorname{EST}\left(\mathrm{x} 10^{4} \mathrm{pls}\right)$ & $\mathrm{ACA}(\%)$ \\
\hline Consórcio & 15,40 & 1,14 & 13,04 & 1,5 \\
\hline Monocultivo & 16,00 & 1,15 & 13,28 & 1,3 \\
\hline
\end{tabular}

* Média difere significativamente pelo teste de Dunnett a 5\% de probabilidade em relação ao monocultivo de sorgo.

${ }^{/ 1}$ Médias seguidas pela mesma letra maiúscula na coluna e minúscula na linha não diferem entre si pelo teste de Tukey a 5\% de probabilidade.

Fonte: Elaboração dos autores. 
A relação $\mathrm{C} / \mathrm{N}$ do sorgo, em geral, obtida no consórcio com a $B$. decumbens, foi inferior em relação as demais espécies que assemelharam-se entre si (Tabela 2). É oportuno ressaltar que a maior relação $\mathrm{C} / \mathrm{N}$ é vantajosa para manter a palhada por mais tempo na superfície do solo (KLIEMANN; BRAZ; SILVEIRA, 2006). Apesar de ter sido utilizado o sorgo granífero, de porte baixo, os resultados obtidos neste trabalho são semelhantes aos de Silva et al. (2009b) e inferiores aos de Calvo, Foloni e Brancalião (2010) que observaram 100 e 55 , respectivamente, para a relação $\mathrm{C} / \mathrm{N}$ do sorgo BRS 800, de maior porte e utilizado para corte e pastejo.

\section{Cultura da braquiária}

Para as características analisadas para a braquiária foram constatadas significâncias para as fontes de variação Monocultivo e Consórcio x Monocultivo para altura de plantas e índice de perfilhamento, além do efeito médio de Braquiária para altura de plantas e relação $\mathrm{C} / \mathrm{N}$ e profundidade de semeadura x Braquiária para esta última variável (Tabela 1).

O consórcio na entrelinha da $B$. brizantha e $B$. decumbens, independente da profundidade de semeadura, proporcionou maior altura de plantas em relação a $B$. ruziziensis (Tabela 3 ). No monocultivo a $B$. decumbens foi a que apresentou o maior porte, devido ao seu melhor desempenho quando cultivada em solos de menor fertilidade (VILELA et al., 1998), como o da área experimental cuja saturação de bases estava abaixo de 32\%. Além disso, a ausência de significância dos valores obtidos em consórcio com o respectivo monocultivo da $B$. decumbens está associado as condições de sombreamento durante o período de cultivo do sorgo. Isto induziu o crescimento das plantas de braquiária em busca de luz, proporcionando, consequentemente, maior altura de plantas.

Tabela 3. Valores médios de altura (AP), índice de perfilhamento (IP), relação $\mathrm{C} / \mathrm{N}(\mathrm{C} / \mathrm{N})$ de plantas de braquiária do consórcio sorgo com $B$. brizantha $(B b), B$. decumbens $(B d)$ e B. ruziziensis $(B r)$ semeadas a 2 e $10 \mathrm{~cm}$ de profundidade na safrinha, Rio Verde-GO, 2009/1.

\begin{tabular}{|c|c|c|c|c|c|c|c|}
\hline Consórcio & \multicolumn{2}{|l|}{$B b$} & \multicolumn{2}{|c|}{$B d$} & \multicolumn{2}{|c|}{$B r$} & Média \\
\hline \multicolumn{8}{|c|}{$\mathrm{AP}(\mathrm{cm})$} \\
\hline $2 \mathrm{~cm}$ & 0,58 & $*$ & 0,65 & & 0,54 & $*$ & 0,59 \\
\hline $10 \mathrm{~cm}$ & 0,70 & $*$ & 0,62 & & 0,54 & $*$ & 0,62 \\
\hline Média & 0,64 & a & 0,63 & $\mathrm{a}$ & 0,54 & $\mathrm{~b}$ & \\
\hline Monocultivo & 0,25 & $\mathrm{~b}$ & 0,67 & $\mathrm{a}$ & 0,22 & $\mathrm{~b}$ & \\
\hline \multicolumn{8}{|c|}{ IP $\left(\mathrm{n}^{\circ}\right.$ de perfilhos planta-1) } \\
\hline $2 \mathrm{~cm}$ & 10,8 & $*$ & 15,6 & & 13,7 & $*$ & 13,33 \\
\hline $10 \mathrm{~cm}$ & 13,2 & $*$ & 16,7 & & 16,0 & $*$ & 15,28 \\
\hline Média & 12,0 & & 16,1 & & 14,8 & & \\
\hline Monocultivo & 24,8 & $\mathrm{~b}$ & 16,6 & $\mathrm{c}$ & 32,1 & $\mathrm{a}$ & \\
\hline \multicolumn{8}{|c|}{$\mathrm{C} / \mathrm{N}$} \\
\hline $2 \mathrm{~cm}$ & $62 \mathrm{Aa}$ & & $36 \mathrm{Bb}$ & & $44 \mathrm{Ab}$ & & 47 \\
\hline $10 \mathrm{~cm}$ & $52 \mathrm{Aa}$ & & $56 \mathrm{Aa}$ & & $39 \mathrm{Aa}$ & & 49 \\
\hline Média & $57 \mathrm{a}$ & & $46 \mathrm{ab}$ & & $41 \mathrm{~b}$ & & \\
\hline Monocultivo & $43 \mathrm{a}$ & & $48 \mathrm{a}$ & & $34 \mathrm{~b}$ & & \\
\hline
\end{tabular}

* Média difere significativamente pelo teste de Dunnett a 5\% de probabilidade em relação ao monocultivo de braquiária.

${ }^{/ 1}$ Médias seguidas pela mesma letra maiúscula na coluna e minúscula na linha não diferem entre si pelo teste de Tukey a 5\% de probabilidade.

Fonte: Elaboração dos autores. 
A atenuação da radiação pela cultura do sorgo (LARCHER, 2003), ocasionando o sombreamento das plantas de braquiária, proporcionou também maior altura e menor índice de perfilhamento (MATTHEW et al., 2000) da B. brizantha e B. ruziziensis em relação aos seus respectivos monocultivos. Nesta condição a $B$. decumbens mostrou-se como a de maior capacidade de perfilhamento.

A semeadura da $B$. decumbens a $10 \mathrm{~cm}$ de profundidade proporcionou maior valor da relação $\mathrm{C} / \mathrm{N}$ em relação a semeadura a $2 \mathrm{~cm}$. Para esta mesma profundidade, o maior valor foi constatado com a $B$. brizantha, superando as demais espécies. $\mathrm{Na}$ semeadura a $10 \mathrm{~cm}$ não foram constatadas diferenças significativas entre as médias dos tratamentos. Ressalta-se que maiores valores da relação $\mathrm{C} / \mathrm{N}$ torna-se vantajoso quando o objetivo é diminuir a degrabilidade da palha na superfície do solo (FLOSS, 2000), principalmente quando a palhada é produzida nas condições do cerrado.

Os menores valores da relação $\mathrm{C} / \mathrm{N}$ obtidos no ensaio são atribuídos a maior competição das plantas de braquiária por nitrogênio quando consorciadas com o sorgo. No ensaio somente esta cultura foi adubada (aplicação de nitrogênio na linha tanto na semeadura como em cobertura) e pelo fato do elemento ser altamente móvel no solo, houve o favorecimento pela absorção pelas plantas de braquiária, diminuindo a relação $\mathrm{C} / \mathrm{N}$. Convém ressaltar que os resultados da relação $\mathrm{C} / \mathrm{N}$ observados no presente estudo, realizado em condições de cerrado, onde o clima favorece a degradação da palhada, são superiores aos de outros trabalhos de pesquisa com $B$. brizantha $\mathrm{cv}$. com $B$. brizantha $\mathrm{cv}$. Marandú (TORRES; PEREIRA; FABIAN, 2008) e Xaraés (RODRIGUES et al., 2007), e semelhantes quando comparados a B. ruziziensis (MENEZES; LEANDRO, 2004). Isto comprova a viabilidade da produção da palhada de braquiária para cobertura do solo.

\section{Sorgo e Braquiária}

A análise dos resultados do rendimento de massa seca do sorgo e da braquiária permitiram constatar significâncias $(p<0,01)$ para as fontes de variação Braquiária, Monocultivo e Consórcio x Monocultivo (Tabela 1). Para o rendimento de proteína bruta total, dentre todas significâncias encontradas, destacam-se a da interação Profundidade de semeadura x Braquiária e Monocultivo $(p<0,01)$ e do contraste Consórcio x Monocultivo $(\mathrm{p}<0,05)$. Para a Cobertura do solo, significâncias $(p<0,01)$ foram obtidas para Profundidade de semeadura, Braquiária e Monocultivo.

A avaliação do rendimento de massa seca total permitiu constatar, em geral, maior valor com uso da $B$. decumbens no consórcio, seguido da $B$. ruziziensis e $B$. brizantha (Tabela 4). O desempenho superior com uso da $B$. decumbens, em solo com saturação de bases baixa, possibilitou a espécie expressar maior potencial produtivo de forragem. Associado a isso, a colheita das panículas do sorgo possibilitou maior incidência de radiação nas plantas de braquiária, o que estimulou o crescimento da gramínea nos 98 dias da entressafra (Figura 1) até que fosse realizado o corte das espécies.

A vantagem do consórcio sorgo com braquiária para produção de forragem na entressafra nos cerrados pode ser comprovada pela superioridade dos valores obtidos no consórcio em relação ao monocultivo de sorgo (Tabela 4). Constatou-se incremento substancial de massa seca no consórcio, devido ao cultivo da braquiária, maximizando a produção de palha para implantação da cultura de verão.

Dentre os diversos tratamentos, destaca-se a associação com a $B$. decumbens, semeada a $10 \mathrm{~cm}$ de profundidade, pois foi a única associação com o sorgo que diferiu do monocultivo da braquiária (Tabela 4). Além da produção de massa seca em consórcio, o sistema permitiu a produção de grãos de sorgo, possibilitando mais uma renda ao produtor rural. Pela diminuição da precipitação com o avanço 
do desenvolvimento das plantas de sorgo e braquiária (Figura 1), limitando o desenvolvimento, os valores de massa seca obtidos no consórcio são inferiores aos de outros trabalhos de pesquisa com o consórcio de milho safrinha com $B$. brizantha cv. Marandú (BORGHI; CRUSCIOL, 2007; EUCLIDES et al., 2008) e B. ruziziensis (RICHART et al., 2010). No monocultivo as braquiárias apresentaram rendimento de massa seca superior ao do sorgo. Esse foi colhido em julho e as braquiárias tiveram um período adicional de crescimento de 98 dias na entressafra, o que resultou em maior acúmulo de biomassa, superando resultados de outros trabalhos de pesquisa com cultivo solteiro da $B$. decumbens (PACIULLO et al., 2003; MACHADO; ASSIS, 2010).

Tabela 4. Valores médios de rendimentos de matéria seca total (RMST) e de proteína bruta total (RPBT), cobertura do solo (CS) e índice de equivalência de área (IEA) do consórcio sorgo com $B$. brizantha $(B b), B$. decumbens $(B d)$ e $B$. ruziziensis $(B r)$ semeadas a 2 e $10 \mathrm{~cm}$ de profundidade na safrinha, Rio Verde-GO, 2009/1.

\begin{tabular}{|c|c|c|c|c|}
\hline Consórcio & $B b$ & $B d$ & $B r$ & Média \\
\hline \multicolumn{5}{|c|}{$\operatorname{RMST}\left(\mathrm{kg} \mathrm{ha}^{-1}\right)$} \\
\hline $2 \mathrm{~cm}$ & 1.252 & $2.357 * 1$ & $1.843 * 1$ & 1.817 \\
\hline $10 \mathrm{~cm}$ & $1.540 * 1$ & $2.560 * 1,2$ & $2.236 * 1$ & 2.112 \\
\hline Média & $1.396 \mathrm{c}$ & $2.458 \mathrm{a}$ & $2.039 \mathrm{~b}$ & \\
\hline \multirow[t]{2}{*}{ Monocultivo } & $B b$ & $B d$ & $\mathrm{Br}$ & Sorgo \\
\hline & $1.668 \mathrm{a}$ & $1.736 \mathrm{a}$ & $1.965 \mathrm{a}$ & $625 \mathrm{~b}$ \\
\hline \multicolumn{5}{|c|}{ RPBT $\left(\mathrm{kg} \mathrm{ha}^{-1}\right)$} \\
\hline $2 \mathrm{~cm}$ & $63 \mathrm{Ac}^{* 1,2}$ & $191 \mathrm{Aa}^{* 1,2}$ & $114 \mathrm{Bb}^{* 1,2}$ & 123 \\
\hline $10 \mathrm{~cm}$ & $67 \mathrm{Ac}^{* 1,2}$ & $135 \mathrm{Bb}^{* 1,2}$ & $151 \mathrm{Aa}^{* 1,2}$ & 118 \\
\hline Média & $65 \mathrm{c}$ & $163 \mathrm{a}$ & $133 \mathrm{~b}$ & \\
\hline \multirow[t]{2}{*}{ Monocultivo } & $B b$ & $B d$ & $B r$ & Sorgo \\
\hline & $136 \mathrm{~b}$ & $95 \mathrm{c}$ & $202 \mathrm{a}$ & $13 \mathrm{~d}$ \\
\hline \multicolumn{5}{|c|}{ CS $(\%)$} \\
\hline $2 \mathrm{~cm}$ & 60,00 & 66,25 & 67,50 & $64,58 \mathrm{~B}$ \\
\hline $10 \mathrm{~cm}$ & 64,50 & 73,75 & 75,00 & $71,08 \mathrm{~A}$ \\
\hline Média & $62,25 \quad b$ & 70,00 & $71,25 \mathrm{a}$ & \\
\hline Monocultivo & $B b$ & $B d$ & $B r$ & Sorgo \\
\hline & $70,50 \mathrm{~b}$ & $83,75 \mathrm{a}$ & $66,25 \mathrm{~b}$ & $42,50 \mathrm{c}$ \\
\hline \multicolumn{5}{|c|}{ IEA } \\
\hline $2 \mathrm{~cm}$ & 1,57 Aa & $1,40 \mathrm{Ba}$ & 1,61 Aa & 1,53 \\
\hline $10 \mathrm{~cm}$ & $1,32 \mathrm{Ab}$ & $1,79 \mathrm{Aa}$ & $1,77 \mathrm{Aa}$ & 1,63 \\
\hline Média & 1,45 & 1,59 & 1,69 & \\
\hline
\end{tabular}

*1, *2: Média difere significativamente pelo teste de Dunnett a 5\% de probabilidade em relação ao monocultivo de sorgo e braquiária respectivamente.

${ }^{11}$ Médias seguidas pela mesma letra maiúscula na coluna e minúscula na linha não diferem entre si pelo teste de Tukey a $5 \%$ de probabilidade.

Fonte: Elaboração dos autores. 
$\mathrm{Na}$ avaliação da cobertura do solo, em geral, a $B$. ruziziensis e a $B$. decumbens foram as que proporcionaram maior valor no consórcio, superando a $B$. brizantha (Tabela 4). No monocultivo, o maior percentual foi obtido com a $B$. decumbens, e o menor pelo sorgo. A vantagem de se efetuar o consórcio de sorgo com braquiária está no fato de que esta espécie incrementa a produção de biomassa até a colheita do sorgo (MACHADO; ASSIS, 2010). Apesar de não ter sido constatada diferenças significativas entre o consórcio e monocultivo, pode-se notar que o menor valor de cobertura no consórcio foi de $60 \%$ e o maior de $75 \%$, e no monocultivo de sorgo, a palhada proporcionou apenas $42,5 \%$ de cobertura vegetal. É oportuno destacar que no momento do corte das braquiárias, tanto no consórcio como no monocultivo, a superfície do solo estava completamente coberta pela biomassa dessa espécie (TIMOSSI; DURIGAN; LEITE, 2007), o que não ocorreu no monocultivo do sorgo.

Outra variável que comprova a eficiência do consórcio sorgo granífero com braquiária é o índice de equivalência de área. Os resultados obtidos foram superiores a 1,0 (um), destacando as associações com a $B$. ruziziensis, independente da profundidade de semeadura, com a $B$. brizantha semeada a $2 \mathrm{~cm}$ e com a $B$. decumbens a $10 \mathrm{~cm}$ (Tabela 4). Ressalta-se que estas associações, exceto com a $B$. decumbens, foram as que proporcionaram maiores rendimentos de grãos de sorgo. Nesses casos, provavelmente, as plantas de braquiária interferiram em menor intensidade com a cultura do sorgo. Demais trabalhos de pesquisa com consórcio de milho (VIEIRA, 1984; FLESCH, 2002; COSTA; SILVA, 2008) e de sorgo na linha (SILVA et al., 2000; 2003) e entrelinha (REZENDE et al., 2001; 2004) permitiram comprovar vantagens na produção de forragem quando as espécies foram consorciadas com soja.

A partir dos resultados obtidos, pode-se comprovar o potencial de produção de grãos e forragem do consórcio sorgo granífero e braquiária na entressafra. $\mathrm{O}$ aumento significativo da produção de palha beneficia o sistema plantio direto (TIMOSSI; DURIGAN; LEITE, 2007), além do consórcio se tornar em uma alternativa interessante para a rotação de culturas nas propriedades agrícolas localizadas no centro-oeste. Com isto o produtor maximizará o uso da área com cultivo de soja no verão, sorgo na safrinha e produção de forragem após a colheita do cereal na entressafra.

Sendo assim pode-se concluir que o sorgo, consorciado na entrelinha com B. ruziziensis, independente da profundidade de semeadura, e com $B$. brizantha, semeada a $2 \mathrm{~cm}$ de profundidade, não reduziu o rendimento de grãos. $\mathrm{O}$ cultivo da braquiária na entrelinha do sorgo possibilitou incrementos no rendimento de massa seca e proteína bruta total. O consórcio de sorgo granífero com braquiária na safrinha mostrou-se como técnica de cultivo eficaz para produção de grãos e forragem na entressafra em condições de cerrado.

\section{Agradecimentos}

Ao Conselho Nacional de Desenvolvimento Científico e Tecnológico (CNPq) pelo auxílio financeiro na realização do trabalho.

\section{Referências}

ALVARENGA, R. C.; COBUCCI, T.; KLUTHCOUSKI, J.; WRUCK, F. J.; CRUZ, J. C.; GONTIJO NETO, M. M. A cultura do milho na integração lavoura-pecuária. Embrapa Milho e Sorgo: Sete Lagoas, 2006. 12 p. (Circular técnica, 80).

ASSIS, G. M. L.; EUCLYDES, R. F.; CRUZ, C. D.; VALLE, C. B. Discriminação de espécies de brachiaria baseada em diferentes grupos de caracteres morfológicos. Revista Brasileira de Zootecnia, Viçosa, v. 32, n. 3, p. 576-584, 2003.

BAUMHARDT, R. L.; TOLK, J. A.; WINTER, S. R. Seeding practices and cultivar maturity effects on simulated dryland grain sorghum yield. Agronomy Journal, Madison, v. 97, n. 3, p. 935-942. 2005. 
BORGHI, E.; CRUSCIOL, C. A. C. Produtividade de milho, espaçamento e modalidade de consorciação com Brachiaria brizantha em sistema plantio direto. Pesquisa Agropecuária Brasileira, Brasília, v. 42, n. 2, p. 163-171, 2007.

BRAZ, A. J. B. P.; PROCÓPIO, S. O.; CARGNELUTTI FILHO, A.; SILVEIRA, P. M.; KLIEMANN, H. J.; COBUCCI, T.; BRAZ, G. B. P. Emergência de plantas daninhas em lavouras de feijão e de trigo após o cultivo de espécies de cobertura de solo. Planta Daninha, Viçosa, v. 24, n. 4, p. 621-628, 2006.

CALVO, C. L.; FOLONI, J. S. S.; BRANCALIÃO, S. R. Produtividade de fitomassa e relação $\mathrm{c} / \mathrm{n}$ de monocultivos e consórcios de guandu-anão, milheto e sorgo em três épocas de corte. Bragantia, Campinas, v. 69, n. 1, p. 7786, 2010.

COELHO, A. M.; WAQUIL, J. M.; KARAM, D.; CASELA, C. R.; RIBAS, P. M. Seja o doutor do seu sorgo. Informações Agronômicas, Piracicaba, n. 100, 2002. 24 p. (Arquivo do Agrônomo, 14).

CORREIA, N. M.; DURIGAN, J. C.; KLINK, U. P. Influência do tipo e da quantidade de resíduos vegetais na eficácia de herbicidas aplicados em pré-emergência na cultura da soja. Bragantia, Campinas, v. 66, n. 1, p. 111-120, 2007.

COSTA, A. S. V.; SILVA, M. B. Sistemas de consórcio milho feijão para região do vale do Rio Doce, Minas Gerais. Ciência e Agrotecnologia, Lavras, v. 32, n. 2, p. 663-667, 2008.

CYSNE, J. R. B.; PITOMBEIRA, J. B. Adaptabilidade e estabilidade de genótipos de sorgo granífero em diferentes ambientes do estado do Ceará. Revista Ciência Agronômica, Fortaleza, v. 43, n. 2, p. 273-278, 2012.

DAN, H. A.; CARRIJO, M. S.; CARNEIRO, D. F.; COSTA, K. A. P.; SILVA, A. G. Desempenho de plantas sorgo granífero sobre condições de sombreamento. Acta Scientiarum-Agronomy, Maringá, v. 32, n. 4, p. 675-679, 2010.

EMPRESA BRASILEIRA DE PESQUISA AGROPECUÁRIA - EMBRAPA. Centro Nacional de Pesquisa de Solos. Manual de métodos de análise de solo. 2. ed. Rio de Janeiro: Embrapa-CNPS, 1997. 212 p.

EUCLIDES, V. P. B.; MACEDO, M. C. M.; VALLE, C. B.; BARBOSA, R. A.; GONÇALVES, W. V. Produção de forragem e características da estrutura do dossel de cultivares de Brachiaria brizantha sob pastejo. Pesquisa Agropecuária Brasileira, Brasília, v. 43, n. 12, p. 18051812, 2008.
FLESCH, R. D. Efeitos temporais e espaciais no consórcio intercalar de milho e feijão. Pesquisa Agropecuária Brasileira, Brasília, v. 37, n. 1, p. 51-56, 2002.

FLOSS, E. Benefícios da biomassa de aveia ao sistema de semeadura direta. Revista Plantio Direto, Passo Fundo, v. 57, n. 1, p. 25-29, 2000.

HECKLER, J. C. Sorgo e girassol no outono-inverno, em sistema plantio direto, no Mato Grosso do Sul, Brasil. Ciência Rural, Santa Maria, v. 32, n. 3, p. 517-520, 2002.

KLIEMANN, H. J.; BRAZ, A. J. P. B.; SILVEIRA, P. M. Taxas de decomposição de resíduos de espécies de cobertura em latossolo vermelho distroférrico. Pesquisa Agropecuária Tropical, Goiânia, v. 36, n. 1, p. 21-28, 2006.

KLUTHCOUSKI, J.; AIDAR, H.; STONE, L. F.; COBUCCI, T. Integração lavoura-pecuária e o manejo de plantas daninhas. Informações Agronômicas, Piracicaba, 2004. p. 1-20. (Encarte técnico, 106).

LARCHER, W. Physiological plant ecology: ecophysiology and stress physiology of functional groups. 4. ed. Berlin: Springer, 2003. 513 p.

MACHADO, L. A. Z.; ASSIS, P. G. G. Produção de palha e forragem por espécies anuais e perenes em sucessão à soja. Pesquisa Agropecuária Brasileira, Brasília, v. 45, n. 4, p. 415-422, 2010.

MALAVOLTA, E.; VITTI, G. C.; OLIVEIRA, S. A. Avaliação do estado nutricional de plantas: princípios e aplicações. 2. ed. Piracicaba: Potafos, 1997. 319 p.

MARIGUELE, K. H.; SILVA, P. S. L. Avaliação dos rendimentos de grãos e forragem de cultivares de sorgo granífero. Caatinga, Mossoró, v. 15, n. 1-2, p. 13-18. 2002.

MATEUS, G. P.; CRUSCIOL, C. A. C.; BORGHI, É.; PARIZ, C. M.; COSTA, C.; SILVEIRA, J. P. F. Adubação nitrogenada de sorgo granífero consorciado com capim em sistema de plantio direto. Pesquisa Agropecuária Brasileira, Brasília, v. 46, n. 10, p. 1161-1169, 2011.

MATTHEW, C.; ASSUERO, S. G.; BLACK, C. K.; HAMILTON, N. R. S. Tiller dynamics of grazed swards. In: LEMAIRE, G.; HODGSON, J.; MORAES, A.; CARVALHO, P. C. F.; NABINGER, C. (Ed.). Grassland ecophysiology and grazing ecology. Wallingford: CABI Publishing, 2000. p. 127-150.

MELLO, L. M. M.; YANO, É. H.; NARIMATSU, K. C. P.; TAKAHASHI, C. M.; BORGHI, É. Integração agricultura-pecuária em plantio direto: produção de forragem e resíduo de palha após pastejo. Engenharia Agrícola, Jaboticabal, v. 24, n. 1, p. 121-129, 2004. 
MENEZES, L. A. S.; LEANDRO, W. M. Avaliação de espécies de coberturas do solo com potencial de uso em sistema de plantio direto. Pesquisa Agropecuária Tropical, Goiânia, v. 34, n. 3, p. 173-180, 2004.

PACIULLO, D. S. C.; AROEIRA, L. J. M.; ALVIM, M. J.; CARVALHO, M. M. Características produtivas e qualitativas de pastagem de braquiária em monocultivo e consorciada com estilosante. Pesquisa Agropecuária Brasileira, Brasília, v. 38, n. 3, p. 421-426, 2003.

PALE, S.; MASON, S. C.; GALUSHA, T. D. Planting time for early-season pearl millet and grain sorghum in Nebraska. Agronomy Journal, Madson, v. 95, n. 4, p. 1047-1053, 2003.

PIMENTEL GOMES, F.; GARCIA, C. H. Estatística aplicada a experimentos agronômicos e florestais. Piracicaba: FEALQ, 2002. 309 p.

REZENDE, P. M.; SILVA, A. G.; BOTREL, É. P.; GOMES, L. L.; GRIS, C. F. CONSÓRCIO SORGOSOJA. VIII. Sistema de corte, cultivares de soja e híbridos de sorgo na produção de forragem das culturas consorciadas na entrelinha e monocultivo do sorgo. Revista Brasileira de Agrociência, Pelotas, v. 10, n. 4, p. 475-481, 2004.

REZENDE, P. M.; SILVA, A. G.; CORTE, E.; BOTREL, E. P. CONSÓRICO SORGO-SOJA. V. Comportamento de híbridos de sorgo e cultivares de soja consorciados na entrelinha no rendimento de forragem. Ciência Rural, Santa Maria, v. 31, n. 3, p. 369-374, 2001.

RICHART, A.; PASLAUSKI, T.; NOZAKI, M. H.; RODRIGUES, C. M.; FEY, R. Desempenho do milho safrinha e da Brachiaria ruziziensis cv. Comum em consórcio. Revista Brasileira de Ciências Agrárias, Recife, v. 5, n. 4, p. 497-502, 2010.

RODRIGUES, R. C.; MOURÃO, G. B.; VALINOTE, A. C.; HERLING, V. R. Reservas orgânicas, relação parte aérea-raiz e C-N e eliminação do meristema apical no capim-xaraés sob doses de nitrogênio e potássio. Ciência Animal Brasileira, Goiânia, v. 8, n. 3, p. 505-514, 2007.

SILVA, A. G.; BARROS, A. S.; SILVA, L. H. C. P.; MORAES, E. B.; PIRES, R.; TEIXEIRA, I. R. Avaliação de cultivares de sorgo granífero na safrinha no sudoeste do Estado de Goiás. Pesquisa Agropecuária Tropical, Goiânia, v. 39, n. 2, p. 168-174, 2009a.
SILVA, A. G.; REZENDE, P. M.; CORTE, E.; MANN, E. N. CONSÓRCIO SORGO-SOJA. III. Seleção de cultivares de sorgo e soja, consorciadas na linha, visando à produção de forragem. Ciência e Agrotecnologia, Lavras, v. 24, n. 4, p. 861-868, 2000.

SILVA, A. G.; REZENDE, P. M.; GRIS, C. F.; GOMES, L. L.; BOTREL, E. P. CONSÓRCIO SORGO-SOJA. IX. Influência de sistemas de cortes na produção de forragens de sorgo e soja consorciados na linha e de sorgo em monocultivo. Ciência e Agrotecnologia, Lavras, v. 27, n. 2, p. 451-461, 2003.

SILVA, M. B.; KLIEMANN, H. J.; SILVEIRA, P. M.; LANNA, A. C. Atributos biológicos do solo sob influência da cobertura vegetal e do sistema de manejo. Pesquisa Agropecuária Brasileira, Brasília, v. 42, n. 12, p. 1755-1761, 2007.

SILVA, P. C. G.; FOLONI, J. S. S.; FABRIS, L. B.; TIRITAN, C. S. Fitomassa e relação C/N em consórcios de sorgo e milho com espécies de cobertura. Pesquisa Agropecuária Brasileira, Brasília, v. 44, n. 11, p. 1504$1512,2009 \mathrm{~b}$.

TAIZ, L.; ZEIGER, E. Plant physiology. 5. ed. Sunderland: Sinauer Associates, 2010. 700 p.

TIMOSSI, P. C.; DURIGAN, J. C.; LEITE, G. J. Formação de palhada por braquiárias para adoção do sistema plantio direto. Bragantia, Campinas, v. 66, n. 4, p. 617-622, 2007.

TORRES, J. L. R.; PEREIRA, M. G.; FABIAN, A. J. Produção de fitomassa por plantas de cobertura e mineralização de seus resíduos em plantio direto. Pesquisa Agropecuária Brasileira, Brasília, v. 43, n. 3, p. 421-428, 2008.

VIEIRA, C. Índice de equivalência de área. Informe Agropecuário, Belo Horizonte, v. 10, n. 118, p. 12-13, 1984.

VILELA, L.; SOARES, W. V.; SOUSA, D. M. G.; MACEDO, M. C. M. Calagem e adubação para pastagens na região do cerrado. Planaltina: EMBRAPA/ CPAC, 1998. 16 p. (Circular técnica, 37). 
